\title{
Towards understanding the novel adhesin function of Candida albicans phosphoglycerate mutase at the pathogen cell surface: some structural analysis of the interactions with human host extracellular matrix proteins*
}

\author{
Dorota Satala1, Aleksandra Zelazna2, Grzegorz Satala, Michal Bukowski², Marcin Zawrot- \\ niak1, Maria Rapala-Kozik¹ and Andrzej Kozik² \\ 1Department of Comparative Biochemistry and Bioanalytics, Faculty of Biochemistry, Biophysics and Biotechnology, Jagiellonian University in \\ Krakow, Kraków, Poland; 'Department of Analytical Biochemistry, Faculty of Biochemistry, Biophysics and Biotechnology, Jagiellonian University \\ in Krakow, Kraków, Poland; ${ }^{3}$ Department of Medicinal Chemistry, Maj Institute of Pharmacology, Polish Academy of Sciences, Kraków, Poland
}

\begin{abstract}
Although many atypical proteinaceous cell wall components that belong to a group of multitasking, "moonlighting" proteins, have been repeatedly identified in numerous pathogenic microorganisms, their novel extracellular functions and secretion mechanisms remain largely unrecognized. In Candida albicans, one of the most common fungal pathogens in humans, phosphoglycerate mutase (Gpm1) - a cytoplasmic enzyme involved in the glycolysis pathway - has been shown to occur on the cell surface and has been identified as a potentially important virulence factor. In this study, we demonstrated tight binding of $C$. albicans $\mathrm{Gpm} 1$ to the candidal cell surface, thus suggesting that the readsorption of soluble Gpm1 from the external environment could be a likely mechanism leading to the presence of this moonlighting protein on the pathogen surface. Several putative Gpm1binding receptors on the yeast surface were identified. The affinities of Gpm1 to human vitronectin (VTR) and fibronectin (FN) were characterized with surface plasmon resonance measurements, and the dissociation constants of the complexes formed were determined to be in the order of $10^{-8} \mathrm{M}$. The internal Gpm1 sequence motifs, directly interacting with VTR (aa 116-158) and FN (aa 138-175) were mapped using chemical crosslinking and mass spectrometry. Synthetic peptides with matching sequences significantly inhibited formation of the Gpm1VTR and Gpm1-FN complexes. A molecular model of the Gpm1-VTR complex was developed. These results provide the first structural insights into the adhesin function of candidal surface-exposed Gpm1.
\end{abstract}

Keywords: Candida albicans, phosphoglycerate mutase, moonlighting proteins, extracellular matrix, vitronectin, fibronectin

Received: 30 September, 2021; revised: 09 October, 2021; accepted: 09 October, 2021; available on-line: 14 November, 2021

घe-mail: andrzej.kozik@uj.edu.pl

*This paper has been published on the occasion of Jubilee Conference entitled "The latest achievements in biochemistry, biophysics and biotechnology - 50 years of history of the Faculty of Biochemistry, Biophysics and Biotechnology of the Jagiellonian University in Kraków" Kraków, September 23-24, 2021.

Acknowledgements of Financial Support: This work was financially supported by the National Science Centre of Poland (grant no. 2016/23/B/NZ6/00089 awarded to A. Kozik).

Abbreviations: BSA, bovine serum albumin; CWP, cell wall proteins; ECM, extracellular matrix; EDC, 1-ethyl-3-(3-dimethylaminopropyl) carbodiimide; FN, fibronectin; GPI, glycosylphosphatidylinositol; Gpm1, phosphoglycerate mutase 1; Gpm1-Bt, biotin-labelled Gpm1; Gpm1-F, fluorescein-labelled Gpm1; HaCaT, an immortalized human keratinocyte line; HUVEC, human umbilical vein endothelia cells; PAI-1, plasminogen activator inhibitor-1; IPTG, isopropyl- $\beta-D-$ thiogalactopyranoside; LC-MS/MS, liquid chromatography-coupled tandem mass spectrometry; micro-RDA, micro-representation difference analysis; MLV, moloney murine leukemia virus reverse transcriptase; NHS, N-hydroxysuccinimide; PBS, phosphate buffered saline; PCR, polymerase chain reaction; R-Gpm1; recombinant phosphoglycerate mutase 1; SDS-PAGE, sodium dodecyl sulphate-polyacrylamide gel electrophoresis; SA-HRP, streptavidin-horseradish peroxidase adduct; SPR, surface plasmon resonance; TMB , 3,3,5,5 tetramethylbenzidine; Tpi, triosephosphate isomerase; TFIIIC, transcription factor IIIC; VTR, vitronectin

\section{INTRODUCTION}

The yeast-like fungus Candida albicans is a commensal inhabitant of the skin and mucous membranes of most healthy individuals in the human population but also one of the most common causes of fungal infections (Guinea, 2014; Ricotta et al., 2021). Candidal infections can proceed in various forms, from relatively harmless surface lesions to multi-organ and systemic candidiasis, the latter often difficult to cure and thus directly life-threatening. A large body of evidence has proven that the pathogenic nature of this yeast is primarily a consequence of significant impairment of the host immune mechanisms (Bongomin et al., 2017; Ho et al., 2021).

The outermost layer of candidal cells is the cell wall. As a dynamic structure, it is continuously remodelled in response to changes in environmental conditions (Sosinska et al., 2011; Vialás et al., 2012; Garcia-Rubio et al., 2020). Among its components, the cell wall proteins (CWP), capable of adhering to host proteins and cells, play a crucial role in colonization of new niches in the host organism and formation of the biofilm structures (Chaffin, 2008; Klis et al., 2009; Höfs et al., 2016; Hoyer \& Cota, 2016). Comparative analyses of the proteinaceous components of the cell wall have shown that the adhesion to the host depends not only on strictly dedicated adhesins, covalently bound to the yeast cell wall mainly through glycosylphosphatidylinositol (GPI) anchors, but also on multiple other proteins, more loosely bound to the cell surface and hence considered as "atypical" cell wall components (Chaffin, 2008). Many of them are multitasking proteins that perform major, evolutionarily conserved functions inside the cell, such as critical involvement in major metabolic pathways. Due to their additional roles, manifested once these proteins appear on the cell surface, they are also known as "moonlighting" proteins (Jeffery, 2003; Karkowska-Ku- 
leta \& Kozik, 2014; Karkowska-Kuleta \& Kozik, 2015; Jeffery, 2019; Satala et al., 2020). The apparent adhesin functions of numerous moonlighting proteins on the cell surface of pathogenic microorganisms determine their contribution to microbial pathogenensis (for reviews see: Karkowska-Kuleta \& Kozik, 2014; Satala et al., 2020). Since these proteins do not have a secretion signal, the mechanism of their appearance on the cell surface remains poorly understood. Also, the biological and structural backgrounds of their novel functions at the new location are unsatisfactorily explained. While enolase is the most widely described moonlighting protein in numerous prokaryotic and eukaryotic organisms (Díaz-Ramos et al., 2012; Henderson \& Martin, 2011), there are also reports of a newly uncovered adhesive function of phosphoglycerate mutase (Gpm1) in pathogenic microorganisms (Poltermann et al., 2007; Zhang et al., 2014; Lopez et al., 2014; Seweryn et al., 2015; Ramos-Hegazy et al., 2020). A primary function of Gpm1 (EC 5.4.2.11) is to convert 3 -phosphoglycerate to 2-phosphoglycerate in the glycolysis pathway and reverse the reaction during gluconeogenesis. In Streptococcus suis, Gpm1 was present in the mixture of cell wall proteins and secretory proteins that additionally possessed FN- and type I collagen-binding activity (Zhang et al., 2014). A micro-representation difference analysis (micro-RDA) combined with Northern blotting showed that GPM1 expression increased during biofilm formation by Staphylococcus aureus, when compared with planktonic cultures (Becker et al., 2001), possibly due to oxygen deprivation in biofilm, but also suggesting a potential role of $\mathrm{Gpm}$ in bacterial pathogenicity. Although surface exposure of Gpm1 was not confirmed for another opportunistic bacterium - Stenotrophomonas maltophilia - the results obtained for a GPM1-deleted mutant with growth kinetics similar to that of the wild-type showed a reduction in the attachment to $\mathrm{CF}$-derived bronchial epithelial cells, and also to a polystyrene surface (RamosHegazy et al., 2020), suggesting that Gpm1 has a role in the adhesion phenomenon. Similarly, in C. albicans yeast, based on immunodetection analyses, Gpm1 was shown to localize to the cell wall of both, the blastospores and hyphae (Poltermann et al., 2007; Vialás et al., 2012). After being exposed on the fungal surface, it could interact with components of the alternative complement pathway - factor $\mathrm{H}$ and factor $\mathrm{H}$-binding protein-like 1, a component of the fibrinolytic system - plasminogen, and the proteins of plasma kinin-generation system (the contact system) - kininogen, prekallikrein and factor XII (Poltermann et al., 2007; Lopez et al., 2014; Seweryn et al., 2015).

A common strategy of pathogenic microbes for initiating infection is recognition and interaction with the host extracellular matrix (ECM) a highly complex structure that provides many sites for microbial attachment. To date, a recombinant C. albicans Gpm1 protein was shown in an ELISA test to bind to human VTR and FN (Lopez et al., 2014). Moreover, the use of recombinant Gpm1-coated latex beads and the GPM1 deletion mutant confirmed the role of this protein in the attachment of yeast to human endothelial cells (HUVEC) and keratinocytes (HaCaT) (Lopez et al., 2014). It was also shown that VTR, present on both types of tested cells, while recognized by Gpm1, provided a bridge for yeast interactions with human cells and possibly ECM (Lopez et al., 2014).

Since information on the transport of moonlighting proteins to the surface of fungal cells is very limited, in the first part of the hereby reported study we tested one possible mechanism - a re-adsorption of soluble Gpm1 from the external environment to the cell surface. It has been reported that the ability of pathogenic cells to bind ECM components might be an effective mechanism contributing to the increased pathogenicity of C. albicans (Klotz, 1994); furthermore, in a previous ELISA-based study, Gpm1 has been indicated as a candidal cell surface partner for the interaction with human VTR and FN (Lopez et al., 2014). Therefore, in the second part of this study we characterized for the first time the interactions of Gpm1 with human ECM proteins in physicochemical and structural terms, based on SPR measurements and chemical cross-linking combined with molecular modeling.

\section{MATERIALS AND METHODS}

\section{Isolation and purification of Gpm1 from C. albicans cell wall}

For yeast culturing and CWP isolation, previously described methods were used (Karkowska-Kuleta et al., 2017). C. albicans ATCC ${ }^{\circledR} 10231^{\mathrm{TM}}$ strain (American Type Culture Collection, Manassas, VA, USA) was cultured in the YPD medium (1\% yeast extract, $2 \%$ soybean peptone and $2 \%$ glucose) for $16 \mathrm{~h}$ at $30^{\circ} \mathrm{C}$ with shaking $(170 \mathrm{rpm})$, then yeasts were cultured in RPMI 1640 (PAA Laboratories GmbH, Pasching, Austria) for $72 \mathrm{~h}$ at $37^{\circ} \mathrm{C}$ with shaking $(170 \mathrm{rpm})$. CWP were extracted by treating cells with $\beta$-1,6-glucanase (TeKaRa Bio Inc., 2 $\mathrm{U}$ of enzyme per $1 \mathrm{~g}$ of wet cell mass), diluted in McIlvaine buffer $(0.2 \mathrm{M}$ disodium hydrogen phosphate in 0.1 $\mathrm{M}$ citric acid, 63.2:36.8 (v/v) pH 6.0, with $0.5 \mathrm{M}$ potassium sodium tartrate), for $4 \mathrm{~h}$ at $37^{\circ} \mathrm{C}$ with gentle shaking. Released proteins were separated from cells by three-step centrifugation $(3000 \mathrm{rpm}$ for $3 \mathrm{~min}, 6000 \mathrm{rpm}$ for $6 \mathrm{~min}$, and $10000 \mathrm{rpm}$ for $10 \mathrm{~min})$. After each step, the supernatant was collected into new eppendorf tubes. Harvested supernatants with a CWP mixture were dialyzed for $48 \mathrm{~h}$ against $20 \mathrm{mM}$ Tris buffer $\mathrm{pH} 8.0$ at $4^{\circ} \mathrm{C}$, with a buffer change after $24 \mathrm{~h}$. CWP were first separated on a ResourceQ column (GE Healthcare, Uppsala, Sweden) with an ÄKTA Pure protein chromatography system (GE Healthcare), with $20 \mathrm{mM}$ Tris, $\mathrm{pH} \mathrm{8.0,} \mathrm{as} \mathrm{the}$ binding buffer and $20 \mathrm{mM}$ Tris with $500 \mathrm{mM} \mathrm{NaCl}, \mathrm{pH}$ 8.0 , as the elution buffer, in a 20 -min linear gradient at a flow rate of $1 \mathrm{ml} / \mathrm{min}$. Gpm1-containing samples were applied onto a gel filtration TSK G3000SW column (Tosoh Bioscience, PA, USA), eluted with $0.1 \mathrm{M} \mathrm{Na}_{2} \mathrm{SO}_{4}$, $0.1 \mathrm{M} \mathrm{NaH}_{2} \mathrm{PO}_{4}, \mathrm{pH}$ 6.7, buffer with a flow rate of 2 $\mathrm{ml} / \mathrm{min}$. After both purification steps, the fractions collected were analyzed by sodium dodecyl sulphate-polyacrylamide gel electrophoresis (SDS-PAGE) in the Laemmli system (Laemmli, 1970) with Coomassie Brilliant Blue R-250 staining, and analyzed with liquid-chromatography-coupled tandem mass spectrometry (LC-MS/MS) (see below).

\section{Expression and purification of recombinant C. albicans Gpm1}

Expression and purification of recombinant Gpm1 (R-Gpm1) of C. albicans were carried out based on the method described in our previous article (Satala et al., 2021). Collected C. albicans cells were suspended in the TRI-Reagent (Sigma Aldrich, St. Louis, MO, USA) and ruptured with the use of glass beads $(425-600 \mu \mathrm{m}$, Sigma Aldrich) and FastPrep Precellys Evolution device (Bertin Technology, Montigny-le-Bretonneu, France) 
with 2 cycles at $45 \mathrm{~s}$ and $6.0 \mathrm{rpm}$. Extraction of C. albicans total RNA was performed according to the standard TRI-Reagent protocol. cDNA was obtained by the use of $2 \mu \mathrm{g}$ RNA, $0.5 \mu \mathrm{g}$ of oligonucleotide (dT)18 primer and $200 \mathrm{U}$ of moloney murine leukemia virus reverse transcriptase (MLV) (Promega, Madison, WI, USA). Amplification of the C. albicans GPM1-coding region was performed by PCR in a C1000 Touch Thermal Cycler (Bio-Rad, Hercules, CA, USA) at specific conditions: $95^{\circ} \mathrm{C}$ for $2 \mathrm{~min}$, followed by 30 cycles of $95^{\circ} \mathrm{C}$ for $30 \mathrm{~s}, 56^{\circ} \mathrm{C}$ for $30 \mathrm{~s}, 74^{\circ} \mathrm{C}$ for $3 \mathrm{~min}$ and $74^{\circ} \mathrm{C}$ for $10 \mathrm{~min}$, with the use of primers: forward 5'GGTGATGATGATGACAAGATGCCAAAGTTAGTTTTAGT'TAGACACG3' and reverse 5'GGAGATGGGAAGTCATTAT'TATT'TCT'T'TGACCT'TGAGCAGCAAC3'. Quality of performed PCR was assessed by $1 \%$ agar electrophoresis, and cDNA was purified with Gel-Out Concentrator Kit (A\&A Biotechnology, Gdynia, Poland). Released cDNA was further processed with aLICator LIC Cloning and Expression Kit (Thermo Scientific Fischer, Waltham, MA, USA). First, it was treated with T4 polymerase and LIC buffer for $5 \mathrm{~min}$, and then the reaction was stopped with $30 \mathrm{mM}$ EDTA. Next, the pLATE51 vector encoding a 6-His tag N-terminal anchor and enterokinase cleavage site was added to the mixture and incubation was continued at room temperature for $5 \mathrm{~min}$. Transformation was carried out with E. coli TOP10 (Thermo Scientific Fischer), followed by a colony PCR, culturing positive colonies and isolation of plasmid DNA with Plasmid Mini Kit (A\&A Biotechnology). Then, plasmids with correct inserts verified by Sanger sequencing were used for transformation of Rosetta $2^{\mathrm{TM}}$ (DE3) E. coli by the heat-freeze method. Cultures of Rosetta 2 were conducted with the use of antibiotics: ampicillin $(100 \mu \mathrm{g} / \mathrm{ml})$ and chloramphenicol (34 $\mu \mathrm{g} / \mathrm{ml}$ ). After cultures reached $\mathrm{OD}_{600} 0.6-0.8$, expression of $\mathrm{Gpm} 1$ was induced by addition of isopropyl- $\beta$-D-thiogalactopyranoside (IPTG), and incubation was continued at $30^{\circ} \mathrm{C}$ for $3 \mathrm{~h}$ with shaking. The cells were collected by centrifugation $\left(6500 \mathrm{rpm}, 30 \mathrm{~min}, 4^{\circ} \mathrm{C}\right)$, suspended in a lysis buffer $\left(50 \mathrm{mM} \mathrm{NaH} \mathrm{PO}_{4}, \mathrm{pH} 8.0,10 \mathrm{mM}\right.$ imidazole, $300 \mathrm{mM} \mathrm{NaCl}, 20 \%$ glycerol) and freezed. The lysis of E. coli cells was performed by sonication to release all of the proteins and centrifuged $(13500 \mathrm{rpm}, 30 \mathrm{~min}$, $\left.4^{\circ} \mathrm{C}\right)$ to harvest supernatants. Supernatants were purified with Ni-NTA Sepharose High Performance affinity matrix at $4^{\circ} \mathrm{C}$ with four buffers: lysis buffer $(50 \mathrm{mM}$ $\mathrm{NaH}_{2} \mathrm{PO}_{4}$, pH $8.0,10 \mathrm{mM}$ imidazole, $300 \mathrm{mM} \mathrm{NaCl}$, $20 \%$ glycerol), two wash buffers (50 mM NaH $\mathrm{PO}_{4}$, $\mathrm{pH}$ 8.0, $20 \mathrm{mM}$ imidazole, $1 \mathrm{M} \mathrm{NaCl}, 20 \%$ glycerol; and $50 \mathrm{mM} \mathrm{NaH} \mathrm{PO}_{4}, \mathrm{pH} 8.0,20 \mathrm{mM}$ imidazole, 300 $\mathrm{mM} \mathrm{NaCl}, 20 \%$ glycerol), and elution buffer $(50 \mathrm{mM}$ $\mathrm{NaH}_{2} \mathrm{PO}_{4}, \mathrm{pH} 8.0,250 \mathrm{mM}$ imidazole, $300 \mathrm{mM} \mathrm{NaCl}$, $20 \%$ glycerol). Selected fractions were dialyzed against 20 $\mathrm{mM}$ Tris, $50 \mathrm{mM} \mathrm{NaCl}, 250 \mathrm{mM}$ imidazole, $20 \%$ glycerol, $\mathrm{pH}$ 8.0, followed by removal of His-Tag by addition of enterokinase $(10 \mathrm{U} / \mu \mathrm{g})$ and incubation for 16 $\mathrm{h}$ at room temperature. The obtained non-tagged protein was purified with Mono Q HR 5/5 $1 \mathrm{ml}$ column (GE Healthcare) with an ÄKTA Pure system at a flow rate of $0.5 \mathrm{ml} / \mathrm{min}$ in a linear gradient between $50 \mathrm{mM}$ $\mathrm{NaH}_{2} \mathrm{PO}_{4}, 100 \mathrm{mM} \mathrm{NaCl}, \mathrm{pH} 8.0$, and $50 \mathrm{mM}$ $\mathrm{NaH}_{2} \mathrm{PO}_{4}, 1 \mathrm{M} \mathrm{NaCl}$ for $130 \mathrm{~min}$.

\section{Analysis of binding of biotin- and fluorescein-labelled Gpm1 to C. albicans cell surface}

For obtaining biotin- and fluorescein-labelled Gpm1 (Gpm1-Bt and Gpm1-F, respectively), R-Gpm1, pre-dia- lyzed against $0.1 \mathrm{M}$ bicarbonate buffer, $\mathrm{pH} 8.3$, was treated with biotin N-hydroxysuccinimide ester $(1 \mathrm{mg} / 100 \mu \mathrm{l}$ of dimethylformamide) (Sigma-Aldrich) or fluorescein N-hydroxysuccinimide ester $(1 \mathrm{mg} / 100 \mu \mathrm{l}$ of dimethyl sulfoxide) (Thermo Fisher Scientific), with a 20 -fold molar excess of the labelling reagent. After $4 \mathrm{~h}$ (Gpm1-Bt) or $1 \mathrm{~h}(\mathrm{Gpm} 1-\mathrm{F})$ incubation at $4^{\circ} \mathrm{C}$, the labelled proteins were dialyzed against phosphate buffered saline (PBS)

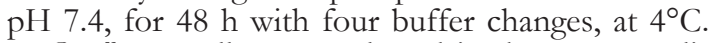

C. albicans cells were cultured in the YPD medium for $16 \mathrm{~h}$ at $30^{\circ} \mathrm{C}$ with $170 \mathrm{rpm}$ shaking, then washed cells were suspended in RPMI 1640 and placed in wells of a MaxiSorp 96-well plate (Sarstedt, Nümbrecht, Germany) $\left(10^{6}\right.$ cells per well) for Gpm1-Bt experiment, or on a special glass-like polymer 96-well plate (CellVis, Mountain View, CA, USA) (104 cells per well) for Gpm1-F, and cultured at $37^{\circ} \mathrm{C}$ for $4 \mathrm{~h}$. In the next step, cells (in the pseudohyphal forms) were washed with $1 \%$ bovine serum albumin (BSA) in PBS (used for washes between each step), and then wells were blocked with 3\% BSA in PBS for $1 \mathrm{~h}$ at $37^{\circ} \mathrm{C}$. Subsequently, washed wells were treated with $50 \mu \mathrm{l}$ of labelled proteins and incubated for $1.5 \mathrm{~h}$ at $37^{\circ} \mathrm{C}$. Then, the wells with bound Gpm1-Bt were incubated with streptavidin-horseradish peroxidase (SA-HRP, MP Biomedicals) for $1 \mathrm{~h}$ at room temperature in the dark. After final washing, the amount of bound protein to candidal cell surface was determined based on SA-HRP/TMB (Sigma Aldrich) detection by addition of $50 \mu \mathrm{l}$ of 3,3',5,5'-tetramethylbenzidine (TMB). The reaction was stopped with $50 \mu \mathrm{l}$ of $2 \mathrm{M} \mathrm{HCl}$, followed by absorbance measurements at $450 \mathrm{~nm}$ (Rapala-Kozik et al., 2008). In experiments with Gpm1-F, after incubation with this protein, the wells were washed and observed under an Olympus IX73 microscope.

Yeast-like cells were obtained as described above, but culturing in RPMI 1640 was omitted. Cells, washed three times with PBS, were placed in eppendorf tubes $\left(3 \times 10^{7}\right.$ cells per tube). The blocking step was skipped; a removal of background signal was performed by tube change before TMB addition. Cells were incubated with $50 \mu \mathrm{l}$ of $\mathrm{Gpm} 1-\mathrm{Bt}$ for $1.5 \mathrm{~h}$ at $37^{\circ} \mathrm{C}$ with gentle shaking, then washed three times with PBS, $\mathrm{pH}$ 7.4. Tube contents were treated with $50 \mu \mathrm{l}$ of SA-HRP (1:4000 in PBS, pH 7.4) and incubated at room temperature for $1 \mathrm{~h}$ in the dark. After washing, cells were transferred to new eppendorf tubes to which $50 \mu$ l of TMB were then added to start the enzymatic reaction.

\section{Identification of Gpm1-binding candidal cell surface proteins}

Identification of surface proteins that apparently interact with Gpm1 was performed by chemical crosslinking, following methods previously described (Kozik et al., 2015). A photoactivatable, cleavable crosslinker sulfo-succinimidyl 2-([4,4'-azipentanamido]ethyl)-1,3'-dithiopropionate (sulfo-SDAD) (Thermo Fisher Scientific) was used. Sulfo-SDAD $(0.5 \mathrm{mM})$ was incubated with 30 $\mu \mathrm{g}$ of Gpm1-Bt in $100 \mu \mathrm{l}$ of PBS for $2 \mathrm{~h}$ in the dark at $4^{\circ} \mathrm{C}$. After stopping the reaction with $50 \mathrm{mM}$ Tris $\mathrm{pH} 7.4$, the sample was dialyzed against PBS, $\mathrm{pH} 7.4$, at $4^{\circ} \mathrm{C}$ overnight to remove excess of the crosslinker. $C$. albicans CWP were added to crosslinker-bearing Gpm1$\mathrm{Bt}$, followed by sample incubation for $1.5 \mathrm{~h}$ at $37^{\circ} \mathrm{C}$ with gentle shaking. Next, the sample was exposed to UV light (365 nm) (6 W, Vilber Lourmat) for $15 \mathrm{~min}$. The samples containing CWP-Gpm1-Bt adducts were incubated with MagnaBind Streptavidin Beads M280 (Thermo Fisher Scientific) for $1 \mathrm{~h}$ at room temperature 
with shaking. A control sample was prepared by addition of CWP to washed streptavidin beads. Unbound and non-biotinylated proteins were removed by washing five times with PBS, $\mathrm{pH}$ 7.4. The dissociation of bound CWP were conducted by boiling at $95^{\circ} \mathrm{C}$ for $30 \mathrm{~min}$ in $30 \mu \mathrm{l}$ of $2.5 \% \beta$-mercaptoethanol and $2 \%$ SDS. Boiled samples were separated by SDS-PAGE and stained with Coomassie Brilliant Blue R-250. Visualized bands of bound proteins were excised, extracted and analyzed by LC-MS/MS, using a method described in detail below.

\section{Mapping the interaction sites between Gpm1 and VTR or FN molecules}

Identification of interaction sites between human ECM proteins and Gpm1 was performed based on our previous publication (Satala et al., 2021). Experiments began with incubations of $0.5 \mathrm{mM}$ sulfo-SDAD with Gpm1 $(30 \mu \mathrm{g})$ and either $30 \mu \mathrm{g}$ of VTR (R\&D Systems, Minneapolis, MN, USA) or $30 \mu \mathrm{g}$ of FN (Sigma Aldrich) in $100 \mu \mathrm{l}$ of PBS in the dark for $2 \mathrm{~h}$ at $4^{\circ} \mathrm{C}$. The order of incubation of Gpm1 or ECM protein with the crosslinker determined which protein could be mapped for spots involved in the other protein-binding. If ECM proteins were first incubated with sulfoSDAD, the Gpm1 molecule was probed for binding sites. In contrast, to map the binding sites on the ECM protein, initial incubation of the crosslinker with Gpm1 was necessary. Thus, after incubation of the first protein with sulfo-SDAD in the dark, the reaction was stopped with $50 \mathrm{mM}$ Tris and the sample was dialyzed against PBS at $4^{\circ} \mathrm{C}$ overnight in the dark. Still in the dark, the second protein was added, followed by sample incubation for $1.5 \mathrm{~h}$ at $37^{\circ} \mathrm{C}$ with gentle shaking. The sample was then exposed to UV light $(365 \mathrm{~nm})$ for $15 \mathrm{~min}$ and then dialyzed against $25 \mathrm{mM}$ ammonium bicarbonate buffer $\left(\mathrm{NH}_{4} \mathrm{HCO}_{3}\right)$ at $4^{\circ} \mathrm{C}$ overnight. To cleave the crosslinker arm, $10 \mathrm{mM} \mathrm{CaCl}_{2}$ and $5 \mathrm{mM}$ dithiothreitol were added to the sample, followed by incubation at $60^{\circ} \mathrm{C}$ for $1 \mathrm{~h}$. The next incubation proceeded for 45 min with $0.1 \%$ iodoacetamide in the dark at room temperature. Proteins were then hydrolyzed by trypsin $\left(10 \mathrm{ng} / \mu \mathrm{l}\right.$ in $\left.25 \mathrm{mM} \mathrm{NH} \mathrm{HCO}_{3}, \mathrm{pH} 8.0\right)$ at $37^{\circ} \mathrm{C}$ overnight. The reaction was stopped with $7 \mu \mathrm{l}$ of $2 \mathrm{M} \mathrm{HCl}$ for $10 \mathrm{~min}$ on ice, and then the sample was evaporated for $2 \mathrm{~h}$, re-dissolved in $10 \%$ acetonitrile with $0.1 \%$ formic acid and analyzed by LC-MS/MS as is described below.

\section{Analysis of protein-protein interactions by surface plasmon resonance (SPR) measurements}

Proteins were immobilized on CM5 chips of the BIACORE 3000 system (GE Healthcare) as previously described (Karkowska-Kuleta et al., 2017). Briefly, immobilization of $\mathrm{Gpm} 1$ was performed via amine groups using 1-ethyl-3-(3-dimethylaminopropyl)carbodiimide (EDC), N-hydroxysuccinimide (NHS) and ethanolamine (Amine Coupling Kit, GE Healthcare) in an acetate buffer at $\mathrm{pH}$ 4.0 , at $25^{\circ} \mathrm{C}$ with a flow rate of $10 \mu \mathrm{l} / \mathrm{min}$. The resonance units $(\mathrm{RU})$ of bound R-Gpm1 and Gpm1 reached about 300. Human ECM proteins were dialyzed against $10 \mathrm{mM}$ HEPES buffer with $150 \mathrm{mM} \mathrm{NaCl}, \mathrm{pH}$ 7.4. Injections of ECM proteins at various concentrations over immobilized Gpm1 were carried out at a $30 \mu \mathrm{l} / \mathrm{min}$ flow rate, with the association and dissociation times of 180 sec. The level of bound ECM proteins to Gpm1 was obtained by SPR signal expressed in RU. A regeneration of the CM5 chip was conducted by the addition of $1 \mathrm{M}$ $\mathrm{HCl}$ with a flow rate of $30 \mu \mathrm{l} / \mathrm{min}$ for $30 \mathrm{sec}$.

\section{Peptide inhibition of VTR- or FN-binding with Gpm1}

Selected peptides were tested for inhibition of the Gpm1-ECM protein interactions in an ELISA-like competitive microplate-based ligand binding assay with final SA-HRP/TMB detection. In experiments on VTR, Gpm1 (10 pmoles per well) was immobilized in the wells of a MaxiSorp 96-well plate (Sarstedt) overnight, at $4^{\circ} \mathrm{C}$. For study of $\mathrm{FN}$, the human protein was immobilized in the microplate ( 2 pmoles per well). The first step after protein immobilization was washing wells with $1 \%$ BSA in PBS, pH 7.4, and blocking unoccupied binding sites within the well with $3 \%$ BSA in PBS, pH 7.4. The wash solution (1\% BSA in PBS, $\mathrm{pH}$ 7.4) was used three times before each experimental step. Blocking of wells lasts $1.5 \mathrm{~h}$ at $37^{\circ} \mathrm{C}$. Then, to the washed wells, a mixture of protein and the competitive peptide was added. In the Gpm1-VTR experiment, the added protein was $100 \mathrm{nM}$ biotin-labelled VTR (final concentration). In contrast, the FN-covered plate was incubated with Gpm1-Bt (at a final concentration of $150 \mathrm{nM}$ ). Peptides were added to wells at various amounts per well. The plates were incubated for $1.5 \mathrm{~h}$ at $37^{\circ} \mathrm{C}$. Finally, $50 \mu \mathrm{l}$ of SA-HRP $(1: 4000$ in PBS, pH 7.4) were added, followed by microplate incubation for $1 \mathrm{~h}$ at room temperature in the dark. The binding level was calculated based on the SA-HRP/TMB detection.

\section{Identification of proteins and mapping interaction sites by mass spectrometry}

The protocol for identification of the electrophoretic band contents was based on a modification of previously described method (Karkowska-Kuleta et al., 2017). In the first step, bands, excised from the electrophoresis gel, were washed twice with $25 \%$ acetonitrile in $25 \mathrm{mM} \mathrm{NH}_{4} \mathrm{HCO}_{3}$, and twice with $50 \%$ acetonitrile in $25 \mathrm{mM} \mathrm{NH}_{4} \mathrm{HCO}_{3}$. Next, to reduce the disulfide bonds, bands were incubated with $10 \mathrm{mM}$ dithiothreitol in $25 \mathrm{mM} \mathrm{NH}_{4} \mathrm{HCO}_{3}$ at $37^{\circ} \mathrm{C}$ for 45 minutes, and then with $50 \mathrm{mM}$ iodoacetamide in $25 \mathrm{mM} \mathrm{NH}_{4} \mathrm{HCO}_{3}$ for $1.5 \mathrm{~h}$ at room temperature in the dark for sulfhydryl groups' alkylation. Preparation of samples for trypsin digestion required double wash with $50 \%$ acetonitrile, followed by incubation in 100\% acetonitrile for $10 \mathrm{~min}$ and drying of bands under fume hood for $15 \mathrm{~min}$. Proteins in the gel bands were hydrolyzed with $13 \mu \mathrm{l}$ of trypsin (Promega) $\left(0.1 \mu \mathrm{g} / 10 \mu \mathrm{l}\right.$ in $\left.25 \mathrm{mM} \mathrm{NH} \mathrm{NHCO}_{3}\right)$ overnight at $37^{\circ} \mathrm{C}$. Afterwards, peptides were released to solution by sonication and dryed in SpeedVac. Dried samples were dissolved in $10 \%$ acetonitrile with $0.1 \%$ formic acid and analyzed by LC-MS/MS. Peptides were separated on Aeris 3.6 um PEPTIDE XB C18 column (Phenomenex) in 10-60\% gradient of $0.1 \%$ formic acid in $80 \%$ acetonitrile with a flow rate of $0.2 \mu \mathrm{l} / \mathrm{min}$ in an ultrahigh-performance liquid chromatography Dionex Ultimate 3000 system (Carlsbad, CA, USA) coupled with a HCT Ultra ion-trap mass spectrometer equipped with an electrospray ionization ion source and an electron-transfer dissociation II fragmentation module (Bruker, Bremen, Germany). Results were analyzed with the Mascot server (v.3.0, Matrix Science, London, UK).

Further steps were made based on a previously described method (Satala et al., 2021). In brief, samples for interaction-site mapping were suspended in 10\% acetonitrile with $0.1 \%$ formic acid and analyzed with the same mass spectrometer as mentioned above. After LC-MS/ MS analysis, the obtained data were checked for sequence coverage and score with Swiss Prot database for both, the human and candidal proteins. The site-map- 
ping based on the closest region to anchored crosslinker was obtained by Mass Matrix PC server Version 4.3 (Xu \& Freitas, 2009)

\section{Molecular modelling of the interaction between C. albicans Gpm1 and human VTR}

Molecular modelling was performed in accordance with a previously described method (Satala et al., 2021). Briefly, the C. albicans Gpm1 crystal structure (SWISSMODEL repository accession number: P82612) and the VTR structure (uniport ID: P04004, vitronectin V65 subunit) previously obtained with the Prime software (Schrödinger Release 2019-1, Schrödinger LLC, New York, NY) were docked using ClusPro 2.0: proteinprotein docking software (Boston University), the server version of which is available at https://cluspro.bu.edu. The resulting fungal protein-human protein complex was analyzed by comparing the distances between experimentally selected Gpm1 amino acid residues and the docked VTR using PyMOL Molecular Graphics System software (version 1.7.2.1; Schrödinger, LLC).

\section{RESULTS}

Exposition of multiple moonlighting proteins on candidal cell surface has been demonstrated by many research group (Chaffin, 2008; Karkowska-Kuleta \& Kozik, 2015; Jeffery et al., 2019; Satala et al., 2021), but the mechanisms of non-classic transport of these cytoplasmic proteins to the cell surface remain mysterious. In this study we present data supporting a hypothesis that significant amounts of moonlighting proteins, such as $\mathrm{Gpm1}$, occur at the infections foci in a fluid phase due to release from extracellular vesicles and/or cytoplasm leakage from damaged or dead cells, and subsequently adsorb on the surface of living cells and moonlight there as supplementary adhesins. Such a mechanism has been recently suggested for candidal enolase (Karkowska-Kuleta et al., 2021). Experiments reported here were carried out on both, isolated natural Gpm1 and R-Gpm1, obtained as electrophoretically pure preparations (Supplementary Fig. S1 at https://ojs.ptbioch.edu.pl/index. $\mathrm{php} / \mathrm{abp} /$ ). First, we used biotin-labelled fungal protein and the SA-HRP/TMB system to detect the association of exogenous Gpm1 with living candidal cells (Fig. 1). Both, the yeast-like cells $\left(3 \times 10^{7}\right.$ per tube $)$ and the filamentous forms (generated from $10^{6}$ cells per well), were found to bind Gpm1 in a ligand concentration-dependent manner (Figs 1A and 1B, respectively), the latter to a capacity higher by two orders of magnitude than the unicellular form. To confirm these findings, we also performed fluorescence-microscopic observations of live filamentous forms of $C$. albicans after coating with Gpm1-F (Fig. 1C).

The next step in current characterization of Gpm1 re-adsorption onto candidal cell surface aimed at identification of specific CWP that possibly serve as docking platforms for Gpm1. Samples containing R-Gpm1 and the mixture of CWP were subjected to crosslinking with sulfo-SDAD - a photoactivatable, heterobifunctional cross-linker with cleavable disulfide bond in its long arm. Putative Gpm1 receptors identified by this method are listed in Table 1. Multiple moonlighting proteins are on this list, with the highest score noted for phosphoglycerate kinase and elongation factor 2. Additionally, we observed peroxiredoxin, transketolase, $60 \mathrm{~S}$ ribosomal protein L10a, pyruvate kinase and enolase. The existence of the latter on candidal cell surface was confirmed in
A

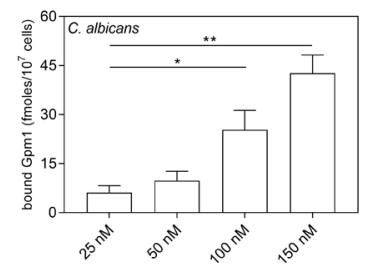

B

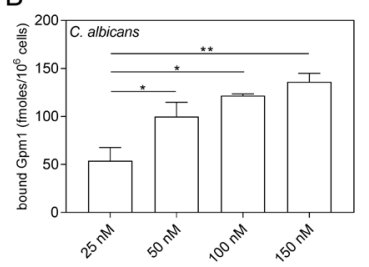

C
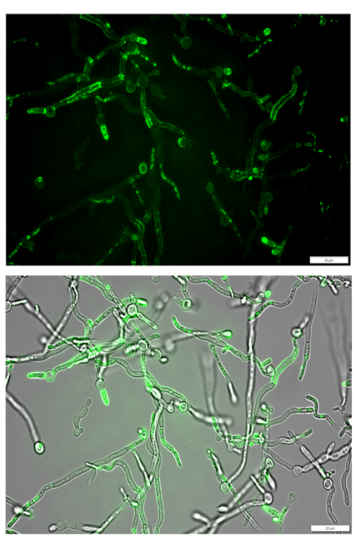

Figure 1. Binding of purified Gpm1 to the surface of the yeastlike and filamentous forms of $C$. albicans cells.

C. albicans blastospores (A) and hyphae (B) were incubated with Gpm1-Bt at a concentration range of 25-150 nM in PBS, pH 7.4, at $37^{\circ} \mathrm{C}$ for $1.5 \mathrm{~h}$. After washing out the unbound protein, the bound Gpm1 was determined with the SA-HRP/TMB system. Statistical significance levels were determined using Student's t test and are marked with * for $p<0.05$ and ${ }^{* *}$ for $p<0.01$. (C) C. albicans filamentous forms, obtained from $10^{4}$ yeast-like cells cultured for $3 \mathrm{~h}$ in the wells of glass microplates in RPMI 1640 at $37^{\circ} \mathrm{C}$, were incubated with $50 \mu \mathrm{l}$ of fluorescein-labeled purified Gpm1 (100 nM) for $1 \mathrm{~h}$ at $37^{\circ} \mathrm{C}$ in PBS buffer, $\mathrm{pH}$ 7.4. After removal of unbound Gpm1, cells were visualized in transmitted light (bottom panel) and green fluorescence (top panel) using an Olympus IX73 microscope.

many reports (Martin et al., 2015; Gil-Bona et al., 2018; Karkowska-Kuleta et al., 2015; Lee et al., 2014; Vialás et al., 2012). Moreover, typical cell surface proteins, such as Als3 - a member of the agglutinin-like sequence protein family, and cell wall protein Rbt1 were also found in our analysis. Interestingly, one of the proteins identified, multifunctional adhesin Als3, has been previously identified as a molecule that mediates binding of another moonlighting protein - enolase to the candidal cell wall (Karkowska-Kuleta et al., 2021). A low identification score for typical adhesins in comparison with moonlighting proteins can result from the particle size and limitations of the method used. Chemical crosslinking requires the availability of reactive sites on the molecule, which in the case of classic proteins of the cell wall is problematic due to strong glycosylation and hydrophobic nature (de Groot et al., 2013). Besides, the chemical crosslinking experiments suggested that Gpm1-Gpm1 interactions, with a high score in Table 1, might be a kind of stacking of these protein molecules on the cell surface. The raw data from these experiments are presented in supplementary Table S1 at https://ojs.ptbioch.edu.pl/index.php/abp/.

The presence of Gpm1 on the cell wall of $C$. albicans cells implies some moonlighting functions of this protein on the candidal surface. It has been proven that many moonlighting proteins bind human ECM, an activity important for a successful invasion of the host (Gründel et al., 2016; Kozik et al., 2015; Satala et al., 2020). In the current study, SPR analyses showed a strong interaction of Gpm1 with ECM proteins (Fig. 2). For both Gpm1 forms, the resonance signal increased with concentration of the ECM protein, injected over the CM5 chip surface with immobilized Gpm1. The equilibrium dissociation constants (KD) for the interactions were found to be comparable between both forms of the fungal protein and were in the order 
Table 1. Identification of C. albicans cell wall proteins that putatively bind candidal Gpm1.

Results were obtained by crosslinking between R-Gpm1-Bt and the mixture of C. albicans CWP, followed by LC-MS/MS analysis.

\begin{tabular}{|c|c|c|c|}
\hline SwissProt protein database accession & Protein name & Molecular mass (kDa) & Sample score \\
\hline PGK_CANAL & Phosphoglycerate kinase & 45.27 & 867 \\
\hline EF2_CANAL & Elongation factor 2 & 93.87 & 513 \\
\hline PMGY_CANAL & Phosphoglycerate mutase & 27.44 & 448 \\
\hline METE_CANAL & $\begin{array}{l}\text { 5-methyltetrahydropteroyltriglutamate-homocyste- } \\
\text { ine methyltransferase }\end{array}$ & 85.76 & 371 \\
\hline TSA1B_CANAL & Peroxiredoxin TSA1-B & 21.96 & 353 \\
\hline ALS3_CANAL & Agglutinin-like protein 3 & 124.31 & 346 \\
\hline SAHH_CANAL & Adenosylhomocysteinase & 49.67 & 230 \\
\hline G6PI_CANAL & Glucose-6-phosphate isomerase & 61.15 & 222 \\
\hline TKT1_CANAX & Transketolase & 73.84 & 210 \\
\hline RL10A_CANAL & $60 S$ ribosomal protein $\mathrm{L} 10 \mathrm{a}$ & 24.48 & 204 \\
\hline NNRD_CANAL & ATP-dependent (S)-NAD(P)H-hydrate dehydratase & 42.10 & 137 \\
\hline ENO1_CANAL & Enolase 1 & 47.20 & 114 \\
\hline SODM_CANAX & Superoxide dismutase [Mn], mitochondrial & 26.21 & 91 \\
\hline KPYK_CANAL & Pyruvate kinase & 55.75 & 90 \\
\hline RBT1_CANAL & Cell wall protein RTB1 & 74.49 & 68 \\
\hline
\end{tabular}

of $10^{-8} \mathrm{M}$, while some variations in the rate constants for various fungal protein-ECM protein pairs were noted (Table 2).

Crosslinking with sulfo-SDAD was also used to map the sites on fungal and human proteins that seem to be involved in these protein-protein interactions. The R-Gpm1-VTR and R-Gpm1-FN were crosslinked and analyzed by LC-MS/MS. The internal motifs of Gpm1, involved in VTR binding included the following sequences: aa 61-80, aa 116-136, aa 138-158 (Table 3). From the VTR side, the aa $354-367$ sequence was probably critical for interaction with Gpm1. For binding of FN, Gpm1 was suggested to engage the aa 138175 motif. Its $\mathrm{N}$-terminal 11 -amino acid sequence (aa 138-158) was identical to that involved in VTR binding, indicating that the regions of Gpm1 molecule contrib-
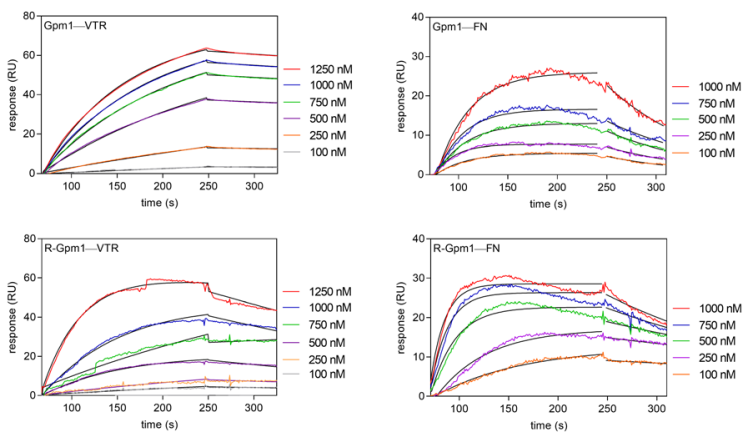

Figure 2. SPR sensograms for interactions between Gpm1 and human VTR or FN.

The upper panels show the results for purified Gpm1 and the bottom panels for R-Gpm1. Sensograms were obtained after injection of VTR or FN at a concentration within a range of 100-1250 nM and at a flow rate of $30 \mu \mathrm{l} / \mathrm{min}$ over a CM5 chip containing Gpm1, immobilized to a level of $300 \mathrm{RU}$. uting to the binding of both ECM proteins significantly overlap. On FN, two Gpm1-binding sequences - aa 904-922 and aa 1117-1129 - were identified. All fitting parameters obtained by the MassMatrix analysis sum-

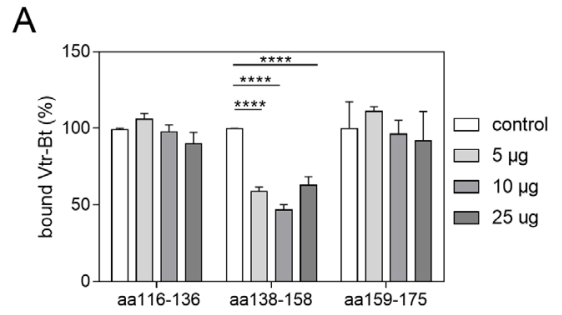

B

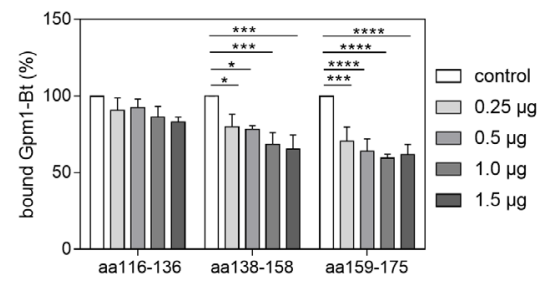

Figure 3. Effects of Gpm1-derived synthetic peptides on binding of VTR (A) or FN (B) to C. albicans R-Gpm1.

(A) The wells of a 96-well microplate were coated with 10 pmoles of R-Gpm 1 at $4^{\circ} \mathrm{C}$ overnight. Peptides with specified Gpm1-derived amino acid sequences were added at amounts of 5, 10 and $25 \mu \mathrm{g}$ per well with VTR-Bt $(100 \mathrm{nM})$ in $50 \mu \mathrm{l}$ of PBS. (B) The wells were coated with 2 pmoles of $\mathrm{FN}$ at $4^{\circ} \mathrm{C}$ overnight. Gpm1-derived peptides at amounts of $0.25,0.5,1.0$ and $1.5 \mu \mathrm{g}$ per ml were added with R-Gpm1-Bt (150 nM) in $50 \mu$ l of PBS. In both cases, a peptide-free well served as a control. Statistical significance levels were determined using Student's $t$ test and are marked with * for $p<0.05$, ${ }^{* *}$ for $p<0.011^{* * *}$ for $p<0.001$ and ${ }^{* * * *}$ for $p<0.0001$. 
Table 2. Kinetic and thermodynamic parameters for the interactions of human VTR or FN with candidal Gpm1, determined by SPR measurements.

The binding parameters for interactions between C. albicans Gpm1 and human VTR or FN were obtained after fitting the data with a 1:1 Langmuir binding model.

\begin{tabular}{llll}
\hline Fungal protein & $k a(1 / \mathrm{Ms})$ & $k d(1 / \mathrm{s})$ & $K D(\mathrm{M})$ \\
\hline VTR-binding & & & \\
\hline C. albicans Gpm1 & $1.83 \times 10^{4} \pm 2.20 \times 10^{3}$ & $4.99 \times 10^{-4} \pm 4.99 \times 10^{-5}$ & $2.73 \times 10^{-8} \pm 2.35 \times 10^{-9}$ \\
\hline C. albicans R-Gpm1 & $1.24 \times 10^{5} \pm 3.89 \times 10^{3}$ & $2.70 \times 10^{-3} \pm 7.66 \times 10^{-5}$ & $2.18 \times 10^{-8} \pm 6.05 \times 10^{-9}$ \\
\hline FN-binding & & & $2.02 \times 10^{-8} \pm 1.08 \times 10^{-9}$ \\
\hline C. albicans Gpm1 & $8.23 \times 10^{4} \pm 6.91 \times 10^{3}$ & $1.66 \times 10^{-3} \pm 9.89 \times 10^{-5}$ & $3.32 \times 10^{-8} \pm 7.36 \times 10^{-9}$ \\
\hline C. albicans R-Gpm1 & $1.92 \times 10^{5} \pm 7.65 \times 10^{3}$ & $6.38 \times 10^{-3} \pm 5.65 \times 10^{-4}$ & \\
\hline
\end{tabular}

Table 3. Mass spectrometry identification of internal sequence motifs in C. albicans Gpm1 and human VTR and FN molecules involved in R-Gpm1-ECM protein interactions.

Peptides were identified by cross-linking analyses of the binding between recombined yeast Gpm1 and human proteins.

\begin{tabular}{|c|c|}
\hline \multicolumn{2}{|l|}{ Peptides of C. albicans R-Gpm1 } \\
\hline VTR-binding & FN-binding \\
\hline $\begin{array}{l}{ }_{61} \text { AIQTANIALDAADQLYVPVK }_{80} \\
{ }_{116} \text { SFDVPPPKIDPKDEYSQVGDR }_{136} \\
{ }_{138} \text { YADVDPAVVPLTESLALVIDR }\end{array}$ & $\begin{array}{l}{ }_{138} \text { YADVDPAVVPLTESLALVIDR }_{158} \\
{ }_{159} \text { LLPYWQDEIAGDLLAGK }_{175}\end{array}$ \\
\hline \multicolumn{2}{|l|}{ R-GpmPeptides of ECM proteins } \\
\hline C. albicans Gpm1-binding VTR peptides & C. albicans Gpm1-binding FN peptides \\
\hline${ }_{354}{ }_{1 Y} Y_{S G G M A P R P S L A K}{ }_{367}$ & $\begin{array}{l}{ }_{904} \text { SDTVPSPRDLQFVEVTDVK }_{922} \\
{ }_{1117} \mathrm{LGVRPSQGGEAPR}_{1129}\end{array}$ \\
\hline
\end{tabular}

marized above are presented in supplementary Table S2 at https://ojs.ptbioch.edu.pl/index.php/abp/.

To further verify the results obtained by the crosslinking method, synthetic peptides with sequences matching those of VTR- and FN-binding Gpm1 motifs listed above were tested for possible inhibitory effects on Gpm1 binding to both ECM proteins (Fig. 3). The results of this set of experiments strongly confirmed that aa 138-158 peptide is involved in interaction with both, the VTR and FN. Addition of 80 pmoles $(10 \mu \mathrm{g})$ per well of aa 138-158 peptide resulted in 60\% decrease of VTR-Bt binding, and a $40 \%$ decrease of $\mathrm{FN}$ binding was observed after addition of 12 pmoles $(1.5 \mu \mathrm{g})$ of this peptide per well. In this competitive binding assay, we were not able to confirm comparable effects of aa 116136 and aa 159-175 peptides on VTR binding to Gpm1, while the latter peptide strongly, down to $40 \%$, displaced FN from the complex with Gpm1. Similar tests with the aa 61-81 peptide showed no displacement effect for both ECM proteins (not shown).
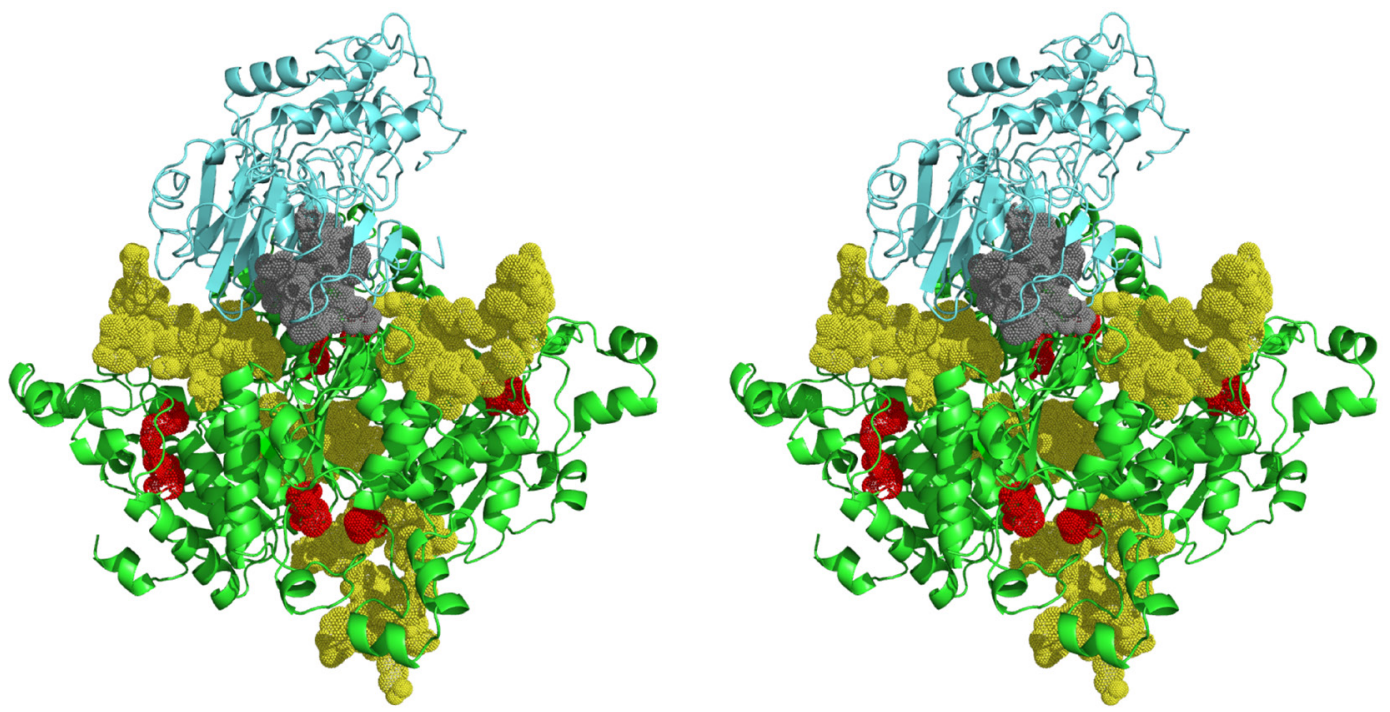

Figure 4. Proposed model of the interaction between C. albicans Gpm1 (green) and human VTR (cyan).

The Gpm1 and VTR peptides identified in the chemical cross-linking experiments are indicated in yellow and gray, respectively. The residues of the catalytic center of Gpm1 are indicated in red. The 3D molecular model is presented in a wall-eyed stereo view. 
Peptides proposed by chemical crosslinking were fitted into the interaction model of $C$. albicans Gpm1. Based on performed analysis, two peptides (aa 116-136, aa 138158) appeared to be involved in a direct interaction with VTR (Fig. 4). In the case of the third peptide (aa 61-80), for which an involvement in the interactions with human proteins could not be confirmed in the inhibition tests with synthetic peptides, this fragment is seen to be involved in interaction between the Gpm1 subunits. In the presented molecular model, the active site residues of the catalytic center in the tetrameric form of Gpm1 were also indicated. Both interaction sites with human protein are distant from the Gpm1 catalytic center, indicative of undisturbed enzymatic activity of Gpm1 during VTR-Gpm1 interaction.

\section{DISCUSSION}

The primary intracellular function of Gpm1 is to catalyze the eighth reaction in the glycolysis pathway. A lack of this enzyme in model organisms, such as $S$. cerevisae, results in inhibition of growth and development, and disturbs gene transcription (Dumay-Odelot et al., 2007; Manaud et al., 1998). Studies on S. cerevisiae mutants with deletion of GPM1 demonstrated a difficulty in the transcription of factor IIIC (TFIIIC) DNA, associated with the polypeptide $\tau 55$, which is partially composed of Gpm1 (Dumay-Odelot et al., 2007; Manaud et al., 1998; Rigden, 2008). Lack of $\tau 55$ or Gpm1 results in instability of the TFIIIC complex structure and in inability to bind DNA. Additionally, C. albicans TFIIIC is known to contain polypeptide $\tau 55$ in its structure and requires Gpm1 for proper function (Dumay-Odelot et al., 2007).

In recent years, numerous studies have demonstrated the presence of Gpm in the cell wall of many microorganisms, including such bacteria as $S$. aureus, Lactobacillus spp. and Stenotrophomonas maltophilia (Becker et al., 2001; Pérez Montoro et al., 2018; Ramos-Hegazy et al., 2020), and yeast-like fungi such as C. parapsilosis, C. tropicalis, C. glabrata and S. cerevisae (Karkowska-Kuleta et al., 2019; Kozik et al., 2015; Motshwene et al., 2003). Nevertheless, the mechanisms of its emergence on the cell surface have not yet been satisfactorily investigated. In our current study, we observed a concentration-dependent deposition of externally added labelled Gpm1 on the surface of living candidal cells, supporting a hypothesis that in vivo Gpm1 may appear on the fungal surface due to re-adsorption of the external soluble protein, constantly present in the surroundings, to some proteinaceous receptors on the living fungal cells. Similar observations have been reported for another moonlighting protein - enolase from C. albicans and Streptococcus pneumoniae (Karkowska-Kuleta et al., 2021; Bergmann et al., 2001). Studies on S. aureus grown under silver-ion stress conditions have shown that the appearance of cytoplasmic proteins outside the cell can be a result of leakage or controlled release (Smith et al., 2013). As has been demonstrated in other proteomic studies, C. albicans and C. glabrata $\mathrm{Gpm} 1$ were variably regulated during response to oxidative stress (Ramírez-Quijas et al., 2015). The authors suggested that Gpm1 is required for their survival in the presence of reactive oxygen forms (Ramírez-Quijas et al., 2015). These findings support a hypothesis that the appearance of many moonlighting proteins on the microbial cell surface is not just accidental, but may be a part of cellular response to changes in the external environment. During colonization and infection of the host organism, one of the major mechanisms to cause changes in the external environment for invading microbes is the influx of the host immune cells to the site of infection. An important part of the host immunity is also activation of the complement system. Two human factors - H and FHL-1 - are responsible for preventing the complement system from activating in an alternative pathway. Activation of this path results in pore production through the microbial cell membrane, disrupting and killing the pathogen cell (Harpf et al., 2020). Previous studies demonstrated that $C$. albicans Gpm1 was a factor $\mathrm{H}$ - and FHL-1 binding protein, which inhibited activation of the alternative pathway of the complement system (Poltermann et al., 2007). For bacteria, it was shown that $S$. aureus cells could respond to silver ion stress conditions with overexpression of proteins involved in the central metabolism, such as Gpm1, virulence and stress response, followed by leakage or release of cytoplasmic proteins (Smith et al., 2013). Pore formation, leakage of cytoplasmic content and eventually death was observed for C. albicans during silver ions stress (Kim et al., 2009). Possibly, similar phenomena underlie the Gpm1 appearance on the candidal cell surface, consequently suggesting that Gpm1's ability to bind various host proteins can help microbes to survive and effectively counteract the host defense during infection. Except for such a hypothetical defense role, another major function of $\mathrm{Gpm} 1$ on the microbial cell surface should be contribution to adhesion to the host cells and proteins, as was presented for many bacterial species, for example the lactobacilli. Bacteria from Lactobacillus spp. mainly colonize the urogenital tract, at a low $\mathrm{pH}$ environment. Gpm1 was detected on the Lactobacillus cell surface and was shown to be an adhesion supporting factor under those unfavorable conditions (Pérez Montoro et al., 2018). Thus, GPM1-deficient mutants presented a definitely lower adhesion ability in acidic environments. Moreover, Gpm1 and an elongation factor were responsible for autoaggregation of Lactobacillus cells, making them much more resistant to harsh conditions (Pérez Montoro et al., 2018). In our current study, one of the proteins identified on the candidal cell surface was elongation factor 2 - another moonlighting protein that apparently binds Gpm1. These results suggested that in C. albicans cells, Gpm1 can be a significant factor that supports adhesion at low $\mathrm{pH}$, a hypothesis especially attractive as the urogenital tract is one of the host niches vulnerable to $C$. albicans infections (Achkar \& Fries, 2010).

SPR analysis presented in this study allowed us to compare the Gpm1 isolated from the surface of C. albicans with its recombinant version, in terms of kinetic and thermodynamic parameters for interaction with representative host targets - ECM proteins, such as VTR and FN. To our knowledge, this is only a second study after our previous work on enolase (Satala et al., 2020) to compare two forms of a moonlighting protein for differences in the potency of interaction with host ligands. In the conducted experiments, we did not notice any significant differences in these terms; the estimated dissociation constants for both studied Gpm1 forms were in a $10^{-8} \mathrm{M}$ order. Similar analyses, based on SPR measurements, were carried out for C. albicans Gpm1 and the proteins of the plasma kinin-generating system (the contact system) - kininogen, prekallikrein and factor XII, and the determined KDs for these candidal protein - human protein complexes were in the order of $10^{-7} \mathrm{M}$ (Seweryn et al., 2015). These results suggest that Gpm1 present on the surface of $C$. albicans can bind a variety of host ligands with similar strength, thus undeniably contributing to pathogen adhesion to the host. 
VTR and FN occur not only in the ECM structure, but also on the various cell surfaces and in the plasma. VTR can be involved in the hemostasis processes, adhesive cells' function and inhibition of the complement system and plasminogen activation (Schvartz et al., 1998). This $75 \mathrm{kDa}$ monomeric glycoprotein is comparable in size with the Gpm1 tetramer $(110 \mathrm{kDa})$. The interaction of VTR with candidal Gpm1, although known for considerable time as a phenomenon (Gründel et al., 2016; Kozik et al., 2015; Lopez et al., 2015), has not yet been elucidated in more detailed structural aspects. Our crosslinking experiment showed a specific VTR peptide (aa 354-367) that probably touches Gpm1 in the complex of these two proteins. This sequence motif is located in the VTR C-terminal domain with significant homology to hemopexin, and overlaps with the sites of interaction with other important ligands, such as heparin (aa 348361) and plasminogen activator inhibitor 1 (PAI-1) (aa 361-371) - an important regulator of plasmin formation and, thus, fibrinolysis (Schvartz et al., 1999; Voss et al., 2013). The major high-affinity site for PAI-1 binding is localized in the N-terminal somatomedin B domain (aa 1-39) (Schar et al., 2008; Schvartz et al., 1999) which, however, was not found to interact with Gpm1. Studies on $S$. aureus, in which one of the cell wall components binds to a similar spot on VTR, suggested that VTR can cover the bacterial cell surface and thus inhibit activation of the complement system (Voss et al., 2013). Thus, C. albicans cells can get many benefits from being covered with this host protein, not only by defending their colonies but also by hiding from the host immune system.

Another host protein, analyzed hereby for Gpm1 binding, was $\mathrm{FN}$ - a $440 \mathrm{kDa}$ dimeric glycoprotein, four times larger than the Gpm1 tetramer. In the FN structure, one can find binding sites for many ligands, such as heparin, fibrin and collagen (Krzyzanowska-Golab et al., 2007). Also, FN possesses cell surface receptor binding domains (Krzyzanowska-Golab et al., 2007). Each chain of FN contains repeated motifs of three types, designated I, II and III, with many glycosylation sites, limiting the protein susceptibility to protease actions (Chen et al., 2009). Hence, it is uncertain whether our cross-linking experiments, followed by trypsin fragmentations, could fully map the sites of FN interactions with Gpm1. Nevertheless, we found putative Gpm1-binding sites (aa 904922 and aa 1117-1129) in the type III domains 4 and 6 , respectively. It should be also mentioned that $\mathrm{FN}$ is one of the proteins with a complicated intrinsic disorder nature, especially in fibronectin type III (Peysselon et al., 2011). All of these FN features, as well as the current lack of information on the actual spatial structure of the above selected domains, precluded a molecular modelling of FN-Gpm1 interactions.

The structure of Gpm1 is well known, but molecular analyses, aimed at locating binding sites for various ligands have not been performed so far. One study showed a possible important function of ATP in stabilizing the structure and dimerization of the Gpm1 molecule (Chang et al., 2012; Gardner et al., 2017). Our study on the interactions between Gpm1 and ECM proteins revealed possible interaction sites at motifs aa 116-158 for VTR and aa 138-175 for FN, with aa 138-158 sequence binding to both host proteins. For the Gpm1-VTR complex, a molecular model was successfully developed, with one VTR molecule bound to the Gpm1 tetramer and the sequence motifs identified on Gpm1 (aa 116-136, aa 138-158) and VTR (aa 354-367) facing together, far away from the residues of the catalytic center.
One important area of research on the moonlighting proteins is to consider them for new disease detection methods. Schistosomatosis, one of the most severe parasitic diseases, is caused by $S$. japonicum, S. mansoni, S. bovis and $S$. haematobiumis. It was shown that in these parasites Gpm1 appears on the cell membrane and is probably responsible for the host-parasite interactions (Zhang et al., 2015). Experiments with buffalos considered the most crucial intermediate hosts for transient schistosomiasis and showed promising results for detecting this parasite using the surface-exposed schistosome Gpm1 (Zhang et al., 2015). In C. albicans, Gpm1 was shown to be immunoreactive during human invasive fungal infection and is now considered as a potential diagnostic marker (Pitarch et al., 2011).

In conclusion, in this study, we presented for the first time the tight binding of $C$. albicans $\mathrm{Gpm} 1$ to the cell surface of this yeast-like fungus, thus suggesting that the readsorption of exogenous soluble Gpm1 could be likely a mechanism of the appearance of this moonlighting protein on the pathogen surface. Moreover, using SPR measurements, the interactions of Gpm1 with human ECM proteins - VTR and FN - were confirmed but also characterized in terms of kinetic and equilibrium constants, which have not been previously reported. For the first time, using chemical crosslinking and mass spectrometry, structural analysis of the complexes formed was performed, indicating sequence motifs directly interacting with each other in the Gpm1-VTR and Gpm1-FN complexes. Finally, a molecular model of Gpm1-VTR complex was developed. The current detailed description of interaction between Gpm1 and ECM proteins contributes to a better understanding of the role of moonlighting proteins in the host-pathogen interaction during candidal infections.

\section{Competing interests}

The authors declare no conflicts of interest.

\section{REFERENCES}

Achkar JM, Fries BC (2010) Candida infections of the genitourinary tract. Clin. Microbiol. Rev. 23: 253-273. https://doi.org//10.1128/ CMR.00076-09

Becker P, Hufnagle W, Peters G, Herrmann M (2001) Detection of differential gene expression in biofilm-forming versus planktonic populations of Staphylococcus aureus using micro-representational-difference analysis. Appl. Environ. Microbiol. 67: 2958-2965. https://doi. org/10.1128/AEM.67.7.2958-2965.2001

Bergmann S, Rohde M, Chhatwal GS, Hammerschmidt S (2001) alphaEnolase of Streptococcus pneumoniae is a plasmin(ogen)-binding protein displayed on the bacterial cell surface. Mol. Microbiol. 40: 1273-1287. https://doi.org/10.1046/j.1365-2958.2001.02448.x

Bongomin F, Gago S, Oladele RO, Denning DW (2017) Global and multi-national prevalence of fungal diseases - estimate precision. J. Fungi. 3: 57. https://doi.org/10.3390/jof3040057.

Chaffin WL (2008) Candida albicans cell wall proteins. Microbiol. Mol. Biol. Rev. 72: 495-544. https://doi.org/10.1128/MMBR.00032-07

Chang Y, Schlebach JP, VerHeul RA, Park C (2012) Simplified proteomics approach to discover protein-ligand interactions. Protein Sci. 21: 1280-1287. https://doi.org/10.1002/pro.2112

Chen R, Jiang X, Sun D, Han G, Wang F, Ye M, Wang L, Zou H (2009) Glycoproteomics analysis of human liver tissue by combination of multiple enzyme digestion and hydrazide chemistry. J. Proteome Res. 8: 651-661. https://doi.org/10.1021/pr8008012

de Groot PWJ, Bader O, de Boer AD, Weig M, Chauhan N (2013) Adhesins in human fungal pathogens: glue with plenty of stick. Eukaryot. Cell. 12: 470-481. https://doi.org/10.1128/EC.00364-12

Dumay-Odelot H, Marck C, Durrieu-Gaillard S, Lefebvre O, Jourdain S, Prochazkova M, Pflieger A, Teichmann M (2007) Identification, molecular cloning, and characterization of the sixth subunit of human transcription factor TFIIIC. J. Biol. Chem. 282: 17179-17189. https://doi.org/10.1074/jbc.M611542200

Díaz-Ramos A, Roig-Borrellas A, García-Melero A, López-Alemany R (2012) $\alpha$-Enolase, a multifunctional protein: its role on pathophysi- 
ological situations. J. Biomed. Biotechnol. 2012: 156795. https://doi. org/10.1155/2012/156795

Garcia-Rubio R, de Oliveira HC, Rivera J, Trevijano-Contador N (2020) The fungal cell wall: Candida, Cryptococcus, and Aspergillus species. Front. Microbiol. 10: 2993 https://doi.org/10.3389/ fmicb.2019.02993

Gardner NW, McGinness SM, Panchal J, Topp EM, Park C (2017) A cooperative folding unit as the structural link for energetic coupling within a protein. Biochemistry 56: 6555-6564. https://doi. org/10.1021/acs.biochem.7b00850

Gil-Bona A, Amador-García A, Gil C, Monteoliva L (2018) The external face of Candida albicans: A proteomic view of the cell surface and the extracellular environment. J. Proteomics 180: 70-79. https:// doi.org/10.1016/j.jprot.2017.12.002

Gründel A, Jacobs E, Dumke R (2016) Interactions of surface-displayed glycolytic enzymes of Mycoplasma pneumoniae with components of the human extracellular matrix. Int. J. Med. Microbiol. 306: 675685. https://dx.doi.org/10.1016/j.iimm.2016.09.001

Guinea J (2014) Global trends in the distribution of Candida species causing candidemia. Clin. Microbiol. Infect. 6: 5-10. https://doi. org/10.1111/1469-0691.12539

Harpf V, Rambach G, Würzner R, Lass-Flörl C, Speth C (2020) Candida and complement: New aspects in an old battle. Front. Immunol. 11: 1471. https://doi.org/10.3389/fimmu.2020.01471

Henderson B, Martin A (2011) Bacterial virulence in the moonlight: multitasking bacterial moonlighting proteins are virulence determinants in infectious disease. Infect. Immun. 79: 3476-3491. https://doi. org/10.1128/IAI.00179-11

Ho J, Camilli G, Griffiths JS, Richardson JP, Kichik N, Naglik JR (2021) Candida albicans and candidalysin in inflammatory disorders and cancer. Immunology 162: 11-16. https://doi.org/10.1111/ imm.13255

Höfs S, Mogavero S, Hube B (2016) Interaction of Candida albicans with host cells: virulence factors, host defense, escape strategies, and the microbiota. J. Microbiol. 54: 149-169. https://doi.org/10.1007/ s12275-016-5514-0

Hoyer LL, Cota E (2016) Candida albicans agglutinin-like sequence (Als) family vignettes: a review of Als protein structure and function. Front. Microbiol. 7: 1-16. https://doi.org/10.3389/fmicb.2016.00280

Jeffery C (2003) Moonlighting proteins: old proteins learning new tricks. Trends. Genet. 19: 415-417. https://doi.org/10.1016/S01689525(03)00167-7

Jeffery C (2019) The use of proteomics studies in identifying moonlighting proteins. Methods Mol. Biol. 1871: 437-443. https://doi. org/10.1007/978-1-4939-8814-3_25

Karkowska-Kuleta J, Kozik A (2014) Moonlighting proteins as virulence factors of pathogenic fungi, parasitic protozoa and multicellular parasites. Mol. Oral Microbiol. 29: 270-283. https://doi. org/10.1111/omi.12078

Karkowska-Kuleta J, Kozik A (2015) Cell wall proteome of pathogenic fungi. Acta Biochim. Pol. 62: 339-351. https://doi.org/10.18388/ abp. 2015_1032

Karkowska-Kuleta J, Wronowska E, Satala D, Zawrotniak M, Bras G, Kozik A, Nobbs AH, Rapala-Kozik M (2021) Als3-mediated attachment of enolase on the surface of Candida albicans cells regulates their interactions with host proteins. Cell. Microbiol. 23: e13297. https://doi.org/10.1111/cmi.13297

Karkowska-Kuleta J, Zajac D, Bochenska O, Kozik A (2015) Surfaceome of pathogenic yeasts, Candida parapsilosis and Candida tropicalis, revealed with the use of cell surface shaving method and shotgun proteomic approach. Acta Biochim. Pol. 62: 807-819. https://doi. org/10.18388/abp.2015_1140

Klis FM, Sosinska GJ, de Groot PW, Brul S (2009) Covalently linked cell wall proteins of Candida albicans and their role in fitness and virulence. FEMS Yeast Res. 9: 1013-1028. https://doi.org/10.1111/ j.1567-1364.2009.00541.x

Klotz SA (1994) Plasma and extracellular matrix proteins mediate in the fate of Candida albicans in the human host. Med. Hypotheses 42: 328-334. https://doi.org/10.1016/0306-9877(94)90008-6

Kozik A, Karkowska-Kuleta J, Zajac D, Bochenska O, Kedracka-Krok S, Jankowska U, Rapala-Kozik M (2015) Fibronectin-, vitronectinand laminin-binding proteins at the cell walls of Candida parapsilosis and Candida tropicalis pathogenic yeasts. BMC Microbiol. 15: 197. https://dx.doi.org/10.1186/s12866-015-0531-4

Kim KJ, Sung WS, Suh BK, Moon SK, Choi JS, Kim JG, Lee DG (2009) Antifungal activity and mode of action of silver nanoparticles on Candida albicans. Biometals 22: 235-242. https://doi. org/10.1007/s10534-008-9159-2

Krzyzanowska-Golab D, Lemanska-Perek A, Katnik-Prastowska I (2007) Fibronectin as an active component of the extracellular matrix. Postepy Hig. Med. Dosw. 61: 655-663 (Online)

Manaud N, Arrebola R, Buffin-Meyer B, Lefebvre O, Voss H, Riva M, Conesa C, Sentenac A (1998) A chimeric subunit of yeast transcription Factor IIIC forms a subcomplex with $\tau 95$. Mol. Cell. Biol. 18: 3191-3200. https://doi.org/10.1128/mcb.18.6.3191
Marín E, Parra-Giraldo CM, Hernández-Haro C, Hernáez ML, Nombela C, Monteoliva L, Gil C (2015) Candida albicans shaving to profile human serum proteins on hyphal surface. Front. Microbiol. 6: 1343. https://doi.org/10.3389/fmicb.2015.01343

Motshwene P, Brandt W, Lindsey G (2003) Significant quantities of the glycolytic enzyme phosphoglycerate mutase are present in the cell wall of yeast Saccharomyces cerevisiae. Biochem. J. 15: 357-362. https://doi.org/10.1042/BJ20021352

Laemmli UK (1970) Cleavage of structural proteins during the assembly of the head of bacteriophage T4. Nature 227: 680-685. https:// doi.org/10.1038/227680a0

Lee PY, Gam LH, Yong VC, Rosli R, Ng KP, Chong PP (2014) Im munoproteomic analysis of antibody response to cell wall-associated proteins of Candida tropicalis. J. Appl. Microbiol. 117: 854-865. https://dx.doi.org/10.1016/j.jprot.2017.12.002

Lopez CM, Wallich R, Riesbeck K, Skerka C, Zipfel PF (2014) Candida albicans uses the surface protein Gpm1 to attach to human endothelial cells and to keratinocytes via the adhesive protein vitronectin. PloS One 9: e90796. https://doi.org/10.1371/journal.pone.0090796

Peysselon F, Xue B, Uversky VN, Ricard-Blum S (2011) Intrinsic disorder of the extracellular matrix. Mol. BioSys. 7: 3353-3365. https:// doi.org/10.1039/c1mb05316g

Pérez Montoro B, Benomar N, Caballero Gómez N, Ennahar S, Horvatovich P, Knapp CW, Gálvez A, Abriouel H (2018) Proteomic analysis of Lactobacillus pentosus for the identification of potential markers involved in acid resistance and their influence on other probiotic features. Food Microbiol. 72: 31-38. https://doi.org/10.1016/j. fm.2017.11.006

Pitarch A, Nombela C, Gil C (2011) Prediction of the clinical outcome in invasive candidiasis patients based on molecular fingerprints of five anti-Candida antibodies in serum. Mol. Cell. Proteomics 10: M110.004010. https://doi.org/10.1074/mcp.M110.004010

Poltermann S, Kunert A, Heide von der M, Eck R, Hartmann A, Zipfel PF (2007) Gpm1p is a factor H-, FHL-1-, and plasminogen-binding surface protein of Candida albicans. J. Biol. Chem. 282: 37537-37544. https://doi.org/10.1074/jbc.M707280200

Ramírez-Quijas MD, López-Romero E, Cuéllar-Cruz M (2015) Proteomic analysis of cell wall in four pathogenic species of Candida exposed to oxidative stress. Microb. Pathog. 87: 1-12. https://doi. org/10.1016/j.micpath.2015.07.011

Ramos-Hegazy L, Chakravarty S, Anderson GG (2020) Phosphoglycerate mutase affects Stenotrophomonas maltophilia attachment to biotic and abiotic surfaces. Microbes Infect. 22: 60-64. https://doi. org/10.1016/j.micinf.2019.08.001

Rapala-Kozik M, Karkowska J, Jacher A, Golda A, Barbasz A, Guevara-Lora I, Kozik A (2008) Kininogen adsorption to the cell surface of Candida spp. Int. Immunopharmacol. 8: 237-241. https://doi. org/10.1016/j.intimp.2007.07.005

Ricotta EE, Lai YL, Babiker A, Strich JR, Kadri SS, Lionakis MS, Prevots DR, Adjemian J (2021) Invasive candidiasis species distribution and trends, United States, 2009-2017. J. Infect. Dis. 223: 12951302. https://doi.org/10.1093/infdis/jiaa502

Rigden DJ (2008) The histidine phosphatase superfamily: Structure and function. Biochem. J. 409: 333-348. https://doi.org/10.1042/ BJ20071097

Satala D, Karkowska-Kuleta J, Zelazna A, Rapala-Kozik M, Kozik A (2020) Moonlighting proteins at the candidal cell surface. Microorganisms 8: 1046. https://doi.org/10.3390/microorganisms8071046

Satala D, Satala G, Zawrotniak M, Kozik A (2021) Candida albicans and Candida glabrata triosephosphate isomerase - a moonlighting protein that can be exposed on the candidal cell surface and bind to human extracellular matrix proteins. BMC Microbiol. 21: 199. https:// doi.org/10.1186/s12866-021-02235-w

Schar CR, Jensen JK, Christensen A, Blouse GE, Andreasen PA, Peterson CB (2008) Characterization of a site on PAI-1 that binds to vitronectin outside of the somatomedin B domain. J. Biol. Chem. 283: 28487-28496. https://doi.org/10.1074/jbc.M804257200

Schvartz I, Seger d, Shaltiel S (1999) Vitronectin. Int. J. Biochem. Cell. Biol. 31: 539-544. https://doi.org/10.1016/S1357-2725(99)00005-9

Seweryn K, Karkowska-Kuleta J, Wolak N, Bochenska O, KedrackaKrok S, Kozik A, Rapala-Kozik M (2015) Kinetic and thermodynamic characterization of the interactions between the components of human plasma kinin-forming system and isolated and purified cell wall proteins of Candida albicans. Acta Biochim. Pol. 62: 825-835. https://doi.org/10.18388/abp.2015_1142

Smith A, McCann M, Kavanagh K (2013) Proteomic analysis of the proteins released from Staphylococcus aureus following exposure to $\mathrm{Ag}(\mathrm{I})$. Toxicol. In Vitro. 27: 1644-1648. https://doi.org/10.1016/j. tiv.2013.04.007

Sosinska GJ, de Koning LJ, de Groot PWJ, Manders EMM, Dekker HL, Hellingwerf KJ, de Koster CG, Klis FM (2011) Mass spectrometric quantification of the adaptations in the wall proteome of Candida albicans in response to ambient pH. Microbiology (Reading) 157: 136-146. https://doi.org/10.1099/mic.0.044206-0

Vialás V, Perumal P, Gutierrez D, Ximénez-Embún P, Nombela C i in. (2012) Cell surface shaving of Candida albicans biofilms, hyphae, and 
yeast form cells. Proteomics 12: 2331-2339. https://doi.org/10.1002/ pmic. 201100588

Voss S, Hallström T, Saleh M, Burchhardt G, Pribyl T, Singh B, Riesbeck K, Zipfel PF, Hammerschmidt S (2013) The choline-binding protein PspC of Streptococcus pneumoniae interacts with the C-terminal heparin-binding domain of vitronectin. J. Biol. Chem. 288: 15614 15627. https://doi.org/10.1074/jbc.M112.443507

Xu H, Freitas MA (2009) MassMatrix: A database search program for rapid characterization of proteins and peptides from tandem mass spectrometry data. Proteomics 9: 1548-1555 https://doi.org/10.1002/ pmic. 200700322
Zhang M, Fu Z, Li C, Han Y, Cao X, Han H, Liu Y, Lu K, Hong Y, Lin J (2015) Screening diagnostic candidates for schistosomiasis from tegument proteins of adult Schistosoma japonicum using an immunoproteomic approach. PLoS Negl. Trop. Dis. 9: 1-17. https:// doi.org/10.1371/journal.pntd.0003454

Zhang H, Zheng J, Yi L, Li Y, Ma Z, Fan H, Lu C (2014) The identification of six novel proteins with fibronectin or collagen type I binding activity from Streptococcus suis serotype 2. J. Microbiol. 52: 963-969. https://doi.org/10.1007/s12275-014-4311-x 